\title{
SIMULTANEOUS MULTIPLE RESPONSES MODELLING, OPTIMISATION AND CORRELATION OF ASIAN TYPE PEANUTS ( ARACHIS HYPOGAEA L.) ROASTING USING RESPONSE SURFACE METHODOLOGY
}

\author{
N.H. Mohd RozalLi, N.L. Chin* and Y.A. Yusof \\ Department of Process and Food Engineering, Faculty of Engineering, \\ Universiti Putra Malaysia, 43400 UPM Serdang, Selangor. Malaysia
}

(Received: 26 July 2012; accepted: 16 November 2012)

\begin{abstract}
The effect of hot-air roasting temperatures and time on colour $\left(\mathrm{L}^{*}\right)$, moisture content $(\%$ d.b.), hardness $(\mathrm{N})$, and fracturability $(\mathrm{mm})$ attributes of two different type of peanuts (China and India origin) were investigated using response surface methodology (RSM). The central composite design (CCD) was used to investigate temperatures ranging from $130-170{ }^{\circ} \mathrm{C}$ (China) and $130-200{ }^{\circ} \mathrm{C}$ (India), while roasting time was from $20-80 \mathrm{~min}$ (China) and 15-50 min (India). The results revealed that temperature and time have significant effect on all the responses. Increase in roasting time and temperature caused a decrease in all the responses for both peanuts. A feasible experimental condition of peanut roasting obtained from the optimisation of simultaneous multiple attributes' response for the China and India peanuts was $152^{\circ} \mathrm{C}$ for $60 \mathrm{~min}$ and $158^{\circ} \mathrm{C}$ for $45 \mathrm{~min}$, respectively. The strongest linear relationship was found between hardness and fracturability, while the weakest was between colour and fracturability for both peanuts.
\end{abstract}

Keywords: RSM, central composite design, peanut roasting, texture quality, physical property

Peanuts and other nuts are increasingly recognised for their benefits in cardiovascular disease (CVD) risk reduction, as acknowledged by a Food and Drug Administration qualified health claim (FDA, 2003) and supported by many clinical studies. The benefits of peanuts extend to the processed form, e.g. peanut butter, where there is evidence that processing, such as roasting and grinding to butter, does not differentially alter the health effects (McKIERNAN et al., 2010) or reduce the amount of protein and total lipids in the new form (Rodrigues et al., 2011).

Even though roasting does not influence the nutritional properties of the peanuts, it contributes to the development of aroma and flavour compounds. This process is important because colour and flavour of peanut butter is dependent on the extent to which brown roasting is allowed to proceed (WoODRoof, 1983). Roasted peanuts are widely consumed as snacks, ingredients in chocolate, confectionary, low-fat beverages, and biscuits or subjected to further process to make peanut paste or peanut butter.

Various time-temperature relationship of roasting as well as types of equipment has been used in previous studies. Most of the roasting are within $130-160{ }^{\circ} \mathrm{C}$ and for about 40-60 min (Gills \& Resurrecion, 2000; Megahed, 2001; Slade \& Levine, 2006; Tomlins et al., 2007). In commercial peanut roasting, the peanuts are roasted in $181.4 \mathrm{~kg}$ lots in a revolving oven, usually a gas-fired roaster, at $160{ }^{\circ} \mathrm{C}$ for $40-60 \mathrm{~min}$ (Woodroof, 1983). WiLLICH (1952) found that the time of roasting peanuts is the most important variable affecting

\footnotetext{
* To whom correspondence should be addressed.

Phone: 6038946 6353; fax: 6038946 4440; e-mail: chinnl@eng.upm.edu.my
} 
the colour of the roasted products. This is later confirmed by TomLins and co-workers (2007) through sensory testing, which showed that by varying the roasting time of peanuts, peanut butter's colour, roasted taste, burnt taste, spotty appearance, stickiness, and smoothness are all affected. In many cases, colour has been the key quality indicator in roasting process of peanut as well as other nuts, such as hazelnuts (ÖZdemir \& Devres, 2000; SAKLAR et al., 2003), pistachio nuts (Kahyaoglu, 2008), and coffee (Mendes et al., 2001). It is because a maximum roasted peanut flavour develops at a distinct roast colour, thus providing useful relationship between colour and flavour. The effectiveness of response surface methodology (RSM) for optimizing food processing from raw to final products is well acknowledged. It has been successfully applied to many roasting process modelling and optimisation problems specifically for nuts (Mendes et al., 2001; KahYaOglu \& Kaya, 2006; KAHYAOgLU, 2008; Nikzadeh \& Sedaghat, 2008; ShakerardeKani et al., 2011). These optimisations of roasting process and product quality of peanuts usually use colour measurement as response, and colour can be accurately analysed instrumentally by using differential scanning colorimeter (DSC) (SLAdE \& LeVINe, 2006) and colorimeter (Smyth et al., 1998).

Beside colour, roasting also affects the moisture content of peanuts, which consequently affects the hardness and crunchiness of roasted peanuts. The effects of roasting on textural properties of different nuts have been determined by other researchers for pistachio (Nikzadeh \& Sedaghat, 2008; Shakerardekani et al., 2011), hazelnut (Demir \& Cronin, 2005), and sesame seeds (KAHYAOGLU \& KAYA, 2006). It is therefore important to include the contribution of other responses, such as moisture content and textural properties, in describing and optimizing the quality of roasted peanuts.

Even though there are available reports on peanut roasting, most of them have used single response, such as fatty acid composition (RoDRIGUES et al., 2011), arachin and non-arachin protein fractions (SLADE \& LEVINE, 2006) or double responses, such as colour and sensory analysis (JoHNSEN et al., 1988; ToMLINS et al., 2007) and equilibrium moisture content with textural properties (HuNG, 2000). With more responses measured, more inputs are available for optimizing the process of peanut roasting process and consequently improve the quality of roasted peanuts. In addition, Pearson's correlation is used as a measure of the strength of linear dependence between any two response variables for evaluating the linear relationship between them. For multiple responses study by SмYтн and co-workers (1998), who considered colour, moisture content, pyrazines volatile compounds, and sensory analysis, they did not report the correlations between the attributes of multiple responses in the peanut roasting process.

Available peanut roasting studies are all using non-Asian type varieties, such as Florunner (Johnsen et al., 1988; Hung \& Chinnan, 1989), Virginia (Smyth et al., 1998; Slade \& Levine, 2006), and peanuts of Brazil's origin (Rodrigues et al., 2011). This study was conducted using two Asian type peanuts, since the production of Asian peanuts are larger than the Western countries. Following reports by USDA's Foreign Agricultural Service, China is by far the largest producer of peanuts (15 200 metric tons) followed by India (6000 metric tons) in the second rank, while the United States is ranked third in terms of world production (1760 metric tons) followed by Nigeria and Indonesia (USDA, 2011). Therefore, the objective of this study was to optimize the roasting process of two Asian peanut types using multiple responses attributes simultaneously, i.e. colour, moisture content, hardness, and fracturability. 


\section{Materials and methods}

\subsection{Materials}

Two types of peanuts originating from China (Virginia variety) and India (Spanish variety TMV-2) were purchased from a local distributor (T.S Maju Sdn. Bhd.) and stored at $7-8{ }^{\circ} \mathrm{C}$ until the experiment.

\subsection{Methods}

1.2.1. Sample preparation. Both China and India type peanuts were spread on the table for manual inspection of peanuts size, damaged and cracked peanuts before the roasting process. Peanuts with odd sizes, outside the range of 13-16 mm for the China type and 9-12 $\mathrm{mm}$ for the India type, were picked out. A digital calliper was used to measure the size of peanuts randomly. The peanuts were roasted in $1 \mathrm{~kg}$ batch in two $14 \times 10 \mathrm{~cm}^{2}$ aluminium trays in a convection oven (Memmert UNB 500, Germany) following run assays in Table 1.

The roasted peanuts were then cooled for $15 \mathrm{~min}$ at room temperature before removing the skin manually. The roasted peanuts were again sorted on a picking table for elimination of the rotten ones, residual material, retaining skin, and damaged kernels. The roasted peanuts were stored in sealed polyethylene storage bag (Reynolds ${ }^{\circledR}$ Zipper Bags, $17.7 \mathrm{~cm} \times 20.3$ $\mathrm{cm} \times 0.005 \mathrm{~cm})$ at $7-10{ }^{\circ} \mathrm{C}$ prior to analysis. The moisture content and colour analysis were made within $24 \mathrm{~h}$ after the roasting, while for hardness test within $48 \mathrm{~h}$, until that the peanuts were kept in air-tight glass jar.

1.2.2. Experimental design. The samples of roasted peanuts were prepared following the central composite design (CCD), which consists of a $2^{2}$ factorial design with design points at \pm 1 , three central points $(0)$, and two levels of axial points at $\pm \alpha$. In this experimental design, $\alpha$ of 1.414 was generated from $\alpha=2^{\mathrm{k} / 4}$, where $\mathrm{k}$ is the number of variables. The minimum number of design points in a CCD is $2^{\mathrm{k}}+2 \mathrm{k}+1$, giving 13 assays from 2 independent variables of roasting time and temperature. The axial points were selected for the design of experiment so that all the parameters were within the desired range. The times and temperatures varied in the range of 20 to $80 \mathrm{~min}$ and between 130 and $170{ }^{\circ} \mathrm{C}$ for the China peanuts, while for India peanuts, they were from 15 to $50 \mathrm{~min}$ and 130 to $200^{\circ} \mathrm{C}$. The treatments for the China and India peanuts were generated using the Minitab software (version 15.1, Minitab Inc., USA). The instrumentally measured dependent variables were responses including colour parameter, $\mathrm{L}^{*}$ to indicate lightness, moisture content, hardness, and fracturability of the roasted peanuts. The experiment was randomised, repeated twice for each peanut variety for the entire set of 13 assays. The mean values from the experiments were taken for analysis.

1.2.3. Colour determination. Colour analysis was made using a colorimeter (UltraScan ${ }^{\circledR}$ PRO, Hunter Associates Laboratory, Inc., VA, USA) set against standard black and white tiles for the instrument calibration. Roasted peanuts were filled inside the optical glass cell (20 mm light path) until it was full. Careful inspection was conducted to minimize the gap between the peanuts. The filled glass cell was kept covered during measurements in the colorimeter. The readings were taken with the apparatus adjusted for reflectance with specular excluded (RSEX), which measures the diffuse reflectance only. The RSEX mode measures the sample's appearance as seen by normal human eyes. The readings were made using the CIELAB system $\left(\mathrm{L}^{*}, \mathrm{a}^{*}, \mathrm{~b}^{*}\right)$ twice; taken from front and rear of the glass cell. For each batch of roasting, 3 samples were taken with two readings each. 
1.2.4. Moisture content determination. Moisture content was determined following the A.O.A.C. official method (A.O.A.C., 1996). Two hundred fifty grams of roasted nuts were ground until a smooth and homogeneous paste was obtained. Approximately $2 \mathrm{~g}$ of paste from each sample was thinly spread on pre-weighed metal moisture dishes $(7 \mathrm{~cm}$ in diameter) and dried in an oven (Memmert UNB 500) for $\pm 6 \mathrm{~h}$ at $100 \pm 5^{\circ} \mathrm{C}$ to reach a constant weight. Covered dishes were placed in a desiccator for $30 \mathrm{~min}$ to reach ambient temperature. The dishes were then re-weighed. Moisture content of the roasted peanuts was reported as loss in weight after drying, following calculations in Eqn. 2.:

$$
\begin{aligned}
& \text { Moisture content (\% wet basis) }=\frac{\mathrm{M}_{\mathrm{H}_{2} \mathrm{O}}}{\mathrm{M}_{\mathrm{H}_{2} \mathrm{O}}+\mathrm{M}_{\text {solids }}} \\
& \text { Moisture content }(\% \text { dry basis })=\frac{\mathrm{M}_{\mathrm{H}_{2} \mathrm{O}}}{\mathrm{M}_{\text {solids }}}
\end{aligned}
$$

1.2.5. Hardness and fracturability test. Texture analysis of peanuts was evaluated in terms of hardness and fracturability using the Kraft knife adapter probe attached to a texture

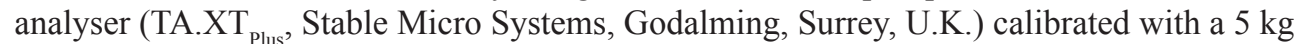
load cell. The test speed was set to $1.00 \mathrm{~mm} \mathrm{~s}^{-1}$, while the post-test speed was $10 \mathrm{~mm} \mathrm{~s}^{-1}$. The penetration distance was taken as half of the diameter of the peanuts, which is $1.50 \mathrm{~mm}$ and $2.00 \mathrm{~mm}$ for the India and China peanuts, respectively. The sample was placed centrally on the cutting block with the blade perpendicular to the nut length and the test was commenced around the mid-region of the sample. The blade then withdraws from the sample and returns to its starting position. Textural properties were derived from the force-time curves. The first peak of first compression in the force-time curves represents the fracturability $(\mathrm{N})$ and the maximum peak of the first compression $(\mathrm{N})$ indicates the hardness value. The test was performed in ten replications per sample.

\subsection{Statistical analysis}

All the responses ( $\mathrm{L}^{*}$ value of colour, moisture content, hardness, and fracturability) were then processed with the same software (Minitab 15.1, Minitab Inc., USA) to evaluate the significant effects of each factor over each response. A second-order polynomial equation in a function of X, was fitted for each factor assessed (MENDES et al., 2001; KAHYAOGLU \& KAYA, 2006; Kahyagglu, 2008; Nikzadeh \& Sedaghat, 2008; Akinoso \& Raji, 2011; Shakerardekani et al., 2011; Youn \& Chung, 2011; De Conto et al., 2012):

$$
\mathrm{Y}=\beta_{0}+\beta_{1} \mathrm{X}_{1}+\beta_{2} \mathrm{X}_{2}+\beta_{12} \mathrm{X}_{1} \mathrm{X}_{2}+\beta_{11} \mathrm{X}_{1}^{2}+\beta_{22} \mathrm{X}_{2}^{2}
$$

where $\mathrm{Y}$ is the predicted response and $\beta_{0}$ is a constant coefficient of the model. The regression coefficients $\left(\beta_{1}\right.$ and $\left.\beta_{2}\right),\left(\beta_{12}\right)$, and $\left(\beta_{11}\right.$ and $\left.\beta_{22}\right)$, respectively, represent linear, interaction and quadratic effects of the model and $X$ is the coded value $(+1,0,-1)$ of the factor indicated by the attached subscripts 1 and 2 for temperature and time, respectively. The adequacy of the models was evaluated by considering $\mathrm{R}^{2}$ value above $90 \%$ and insignificant lack-of-fit test $(\mathrm{P}>0.05)$ as good indicators of fitting. 
Optimisation analysis was also performed using the same software. The desirability functions of RSM were used to determine the optimum roasting conditions of peanuts. The optimisation and individual desirability of each response was obtained by defining the goals and boundaries and later combined them with composite desirability into a single measure (TAN et al., 2012). The highest desirability value is 1 . The optimum quality of roasted peanuts was determined following target values of $L^{*}=49.20$ and moisture content of $1.60 \%$, with minimum hardness and fracturability. The $\mathrm{L}^{*}$ value of 49.20 refers to a previous study, which indicated a medium roast of peanuts (JOHNSEN et al., 1988) and was used as colour indicator for roasted peanuts for producing peanut butter or paste (GILls \& RESURRECION, 2000). The moisture content of a leading commercial peanut butter in Malaysia (Lady's Choice ${ }^{\mathrm{TM}}$ smooth and spreadable peanut butter, Unilever (Malaysia) Holdings Sdn. Bhd.) is approximately $1.6 \pm 0.34 \%$, as was measured priorly.

The responses' data were also subjected to Pearson's correlation analysis using the same software to measure the extent to which two continuous variables are linearly related at $\alpha$-level of 0.05 . A correlation is a number between -1 and +1 that measures the degree of association between two variables. A positive value for the correlation implies a positive association, while a negative value for the correlation implies a negative or inverse association between variables. The coefficient of 0 indicates no linear relationship. In this study $\alpha$-level of 0.05 was used to prove whether the correlation deviates significantly from coefficient of 0 $(\mathrm{P} \leq 0.05)$.

\section{Results and discussion}

\subsection{Physical properties of raw peanuts}

Table 1 shows the physical and textural properties of both types of raw peanuts. The peanuts differed physically in sizes and textural properties, i.e. hardness and fracturability. However, the width/length ratio, moisture content and colour of the China and India peanuts were quite similar. The moisture content of the peanuts from this study was higher even though the width/length ratio is lower than those of Turkey origins (COM and NC-7 cultivars) (ÖZCAN \& SEVEN, 2003).

Table 1. Physical properties of raw peanut of China and India

\begin{tabular}{lrr}
\hline Parameter & \multicolumn{1}{c}{ China } & \multicolumn{1}{c}{ India } \\
\hline Average length $(\mathrm{mm})$ & $14.43 \pm 1.72$ & $9.78 \pm 1.47$ \\
Average diameter $(\mathrm{mm})$ & $4.13 \pm 0.93$ & $3.0 \pm 0.54$ \\
Colour $\left(\mathrm{L}^{*}\right)$ & $58.66 \pm 1.53$ & $59.47 \pm 1.04$ \\
Moisture content $(\%$ dry basis) & $6.51 \pm 0.16$ & $6.4 \pm 0.14$ \\
Hardness $(\mathrm{N})$ & $9.64 \pm 0.55$ & $4.93 \pm 0.82$ \\
Fracturability $(\mathrm{mm})$ & $1.36 \pm 0.09$ & $0.95 \pm 0.16$ \\
\hline
\end{tabular}

\subsection{Modelling the effects}

The equation models for colour $\left(\mathrm{Y}_{1}\right)$, moisture content $\left(\mathrm{Y}_{2}\right)$, hardness $\left(\mathrm{Y}_{3}\right)$, and fracturability $\left(\mathrm{Y}_{4}\right)$ for both type of peanuts, were fitted as follow: 
For China peanuts,

$$
\begin{gathered}
\mathrm{Y}_{1}=52.44-7.53 \mathrm{X}_{1}-6.60 \mathrm{X}_{2}-2.90 \mathrm{X}_{1} \mathrm{X}_{2}-4.03 \mathrm{X}_{1} \mathrm{X}_{1}-0.42 \mathrm{X}_{2} \mathrm{X}_{2} \\
\mathrm{Y}_{2}=2.24-1.15 \mathrm{X}_{1}-1.59 \mathrm{X}_{2}-0.05 \mathrm{X}_{1} \mathrm{X}_{1}+0.50 \mathrm{X}_{2} \mathrm{X}_{2}-0.26 \mathrm{X}_{1} \mathrm{X}_{2} \\
\mathrm{Y}_{3}=587.55-65.13 \mathrm{X}_{1}-148.25 \mathrm{X}_{2}+67.13 \mathrm{X}_{1} \mathrm{X}_{2}+21.61 \mathrm{X}_{1} \mathrm{X}_{1}+130.05 \mathrm{X}_{2} \mathrm{X}_{2} \\
\mathrm{Y}_{4}=0.86-0.08 \mathrm{X}_{1}-0.21 \mathrm{X}_{2}+0.04 \mathrm{X}_{1} \mathrm{X}_{2}+0.04 \mathrm{X}_{1} \mathrm{X}-0.25 \mathrm{X}_{2} \mathrm{X}_{2}
\end{gathered}
$$

For India peanuts,

$$
\begin{gathered}
Y_{1}=49.08-14.52 X_{1}-7.22 X_{2}-12.79 X_{1} X_{2}-7.60 X_{1} X_{1}+2.41 X_{2} X_{2} \\
Y_{2}=2.05-1.11 X_{1}-1.23 X_{2}-0.01 X_{1} X_{2}+0.66 X_{1} X_{1}+0.11 X_{2} X_{2} \\
Y_{3}=429.43-56.97 X_{1}-56.27 X_{2}+40.41 X_{1} X_{2}-7.93 X_{1} X_{-1.46 X_{2} X_{2}} \\
Y_{4}=0.72-0.19 X_{1}-0.11 X_{2}+0.16 X_{1} X_{2}+0.06 X_{1} X_{1}+0.08 X_{2} X_{2}
\end{gathered}
$$

The models were constructed by substituting the coefficient value from the CCD analysis into equation (3) and validated through the coefficient of determination, $\mathrm{R}^{2}$, which represents how well future outcomes are likely to be predicted by the model and also the non-significance of lack of fit $(\mathrm{P}>0.05)$. The $\mathrm{R}^{2}$ for colour, moisture content, hardness, and fracturability of China peanuts were $0.952,0.977,0.947$, and 0.964 , respectively, while for India peanuts were $0.962,0.907,0.876$, and 0.954 . The lack of fit was insignificant for all the models $(\mathrm{P}>0.05)$. This leads to the conclusion that predictive models can be developed at any values of the parameters within the experimental range.

Predictive modelling produced from CCD was also reported by other researchers providing significant and useful information on predicting simultaneous multiple responses of the roasting process. Recent study by DE CONTO and co-workers (2012) has shown that the predictive model produced from CCD is useful in evaluating both technological and sensory quality of white pan bread. The nutritional and organoleptic properties of coffee-like maize beverage were adequately related to the roasting parameters by using quadratic model generated from CCD (Youn \& Chung, 2011). Shakerardekani and co-workers (2011) concluded that $\mathrm{CCD}$ could be used to predict satisfactory models for describing the changes in colour and hardness of pistachio as influenced by roasting time and temperature. AkINOSO and RAJI (2011) also successfully developed predictive models, which had good fits in predicting the effect of roasting time and temperature of locust bean on free fatty acids, oil yield, colour, oil stability, anisidine value, and specific gravity responses. The predictive models for the colour variables $\left(\mathrm{L}^{*}, \mathrm{a}^{*}\right.$, and $\left.\mathrm{b}^{*}\right)$ in optimizing the roasting process of robusta coffee showed good predictive capacity and is proposed by MENDES and co-workers (2001) to be used as tools in the process control of coffee roasting.

\subsection{Effect of roasting temperature and time}

The responses which are $\mathrm{L}^{*}$ value of colour, moisture content, hardness, and fracturability of roasted peanuts were analysed using coded values to evaluate the significant effects of the 
roasting temperature and time. Units of measure for each response are normalized by using coded values so that they are comparable as they are now dimensionless. The coefficients, $\beta$ and $P$ values for each response are summarized in Table 2. Temperature and time factors were found to have significant effect on all the responses $(\mathrm{P}<0.05)$ for both type of peanuts. Similarly, the quadratic effects of temperature also has pronounced effect on colour for both peanuts $(\mathrm{P}<0.05)$. The quadratic effects of temperature were also affecting moisture content and fracturability of India peanuts although it was less significant $(P<0.10)$. The moisture content, hardness, and fracturability of China peanuts and fracturability of India peanuts were significantly affected by the quadratic effects of time $(\mathrm{P}<0.05)$. The quadratic effects of both factors to other responses were small $(\mathrm{P}>0.20)$. The interaction effect only had significant influence on the colour and fracturability of India peanuts $(\mathrm{P}<0.05)$. The interaction effects were also affecting the colour and hardness responses of China peanuts, and hardness responses of India peanuts, although it was less significant $(\mathrm{P}<0.15)$. The other responses were the least affected by interaction effects $(\mathrm{P}>0.20)$. The results suggest that over the range of the factors studied, roasting temperature is the most important factor for promoting colour development during peanut roasting regardless of the peanuts origin. The same result was reported for the roasting of pistachio nut (KAHYAOGLU, 2008) and sesame seeds (KAHYAOgLu \& KaYA, 2006). Even though Tombins and co-workers (2007) found that time is the factor governing colour changes in peanut roasting, the results are incomparable, since they only studied the effects of time variation. On the other hand, roasting time is a more effective factor promoting the changes in moisture content and textural properties of both types of peanuts. Different results were reported for sesame seeds (KAHYAOGLU \& KAYA, 2006) and hazelnut (SAKLAR et al., 2003) where temperature was the main factor affecting their texture quality during roasting. The main factor governing the texture changes during roasting might vary between different types of nut depending on their unique structural characteristics. Quality of nuts roasted at the same roasting condition might also be varying with roasting equipment.

To aid visualisation, the response surfaces for colour, moisture content, hardness, and fracturability are presented in Figs 1, 2, 3, and 4, respectively. All the responses decreased with increase in roasting time and temperature (Figs 1-4). The observed results are in agreement with previous studies (KAHYAOGLU \& KAYA, 2006; SHAKERARDEKANI et al., 2011) on texture and physical changes during pistachios and sesame seeds roasting, respectively. During a roasting process, as browning and caramelisation reactions progress, the brown pigments increase (SAKLAR et al., 2003) resulting in decrease of the L-value of the colour. Roasting is also a method used to reduce the moisture content of a product, which then changes its textural quality. Hung and CHINNAN (1989) showed that the energy required to shear-compress $50 \mathrm{~g}$ of roasted peanuts decreased by $7.0 \mathrm{~J}$ as the moisture content decreased $4 \%$ for peanut dried at $54{ }^{\circ} \mathrm{C}$ for $5 \mathrm{~h}$. Peanut's exterior hardness probably correlates with consumer perceptions of 'first bite' hardness, a high profile textural characteristic of most nuts. Fracturability is the force applied to cause a food sample to break or fracture which is similar to brittleness or crispness. The decrease in textural properties shows that at the same deformation, the force required to break the peanuts decreased with an increase in roasting time and temperature. The force is inversely correlated with crispness. SAKLAR and co-workers (2003) predicted that crispness and crunchiness of roasted hazelnuts increased due to the increase in the volume of the intercellular spaces as roasting temperature increased.

However, there were slight differences between both peanuts in its response trend. Generally, the China peanuts are adequately described by quadratic models for all the 
responses (Figs 1A-4A). The significant quadratic terms of either roasting temperature or time probably caused the curvatures in the response surfaces for all responses for China peanuts (Figs 1A-4A). For the India peanuts, the response surfaces are a plane as displayed in Figs $2 \mathrm{~B}$ and $3 \mathrm{~B}$ for moisture content and hardness responses, respectively, due to their more significant linear term. The more significant interaction effect "twists" the plane in Figs $1 \mathrm{~B}$ and $4 \mathrm{~B}$ for colour and fracturability responses of India peanuts, respectively. The size difference between both peanuts might be an appropriate explanation for these differences. The heat during the roasting process could have distributed more evenly to the surfaces of India peanuts given its smaller size compared to the China peanuts. As such a gradual decrement in the responses is observed in the India peanuts when roasting time and temperature increased. The China peanuts, which are bigger in size, on the other hand needed longer time or higher temperature at any roasting point to gain the response effects. Previous studies by SAKLAR and co-workers (1999) reported that the textural properties of roasted hazelnuts, which are of different shapes and sizes, have different length and direction of initial fracture.

Table 2. Regression coefficients and the associated probability (P value) for each response

\begin{tabular}{|c|c|c|c|c|c|c|c|c|c|}
\hline \multirow[t]{2}{*}{ Origin } & \multirow[t]{2}{*}{ Term } & \multicolumn{2}{|c|}{ Colour, $\mathrm{Y}_{1}$} & \multicolumn{2}{|c|}{ Moisture content, $\mathrm{Y}_{2}$} & \multicolumn{2}{|c|}{ Hardness, $\mathrm{Y}_{3}$} & \multicolumn{2}{|c|}{ Fracturability, $\mathrm{Y}_{4}$} \\
\hline & & $\beta$ & $\mathrm{P}$ & $\beta$ & $\mathrm{P}$ & $\beta$ & $\mathrm{P}$ & $\beta$ & $\mathrm{P}$ \\
\hline \multirow[t]{6}{*}{ China } & Constant & 52.44 & $0.00^{*}$ & 2.24 & $0.00 *$ & 587.55 & $0.00 *$ & 0.86 & $0.00 *$ \\
\hline & $X_{1}$ & -7.53 & $0.00 *$ & -1.15 & $0.00 *$ & -65.13 & $0.01 *$ & -0.08 & $0.01 *$ \\
\hline & $\mathrm{X}_{2}$ & -6.60 & $0.00 *$ & -1.56 & $0.00 *$ & -148.25 & $0.00 *$ & -0.21 & $0.00 *$ \\
\hline & $X_{1} \cdot X_{1}$ & -4.03 & $0.02 *$ & -0.05 & $0.80 * * * *$ & 21.61 & $0.41 * * * *$ & 0.04 & $0.25 * * * *$ \\
\hline & $\mathrm{X}_{2} \cdot \mathrm{X}_{2}$ & -0.42 & $0.76 * * * *$ & 0.50 & $0.02 * * * *$ & 130.05 & $0.00 *$ & 0.25 & $0.00 *$ \\
\hline & $\mathrm{X}_{1} \cdot \mathrm{X}_{2}$ & -2.90 & $0.14 * * *$ & -0.26 & $0.29 * * * *$ & 67.13 & $0.08 * *$ & 0.04 & 0.30 **** \\
\hline \multirow[t]{6}{*}{ India } & Constant & 49.08 & $0.00 *$ & 2.05 & $0.00^{*}$ & 429.43 & $0.00 *$ & 0.72 & $0.00 *$ \\
\hline & $\mathrm{X}_{1}$ & -14.52 & $0.00 *$ & -1.11 & $0.00^{*}$ & -56.97 & $0.00 *$ & -0.19 & $0.00 *$ \\
\hline & $\mathrm{X}_{2}$ & -7.22 & $0.00 *$ & -1.23 & $0.00 *$ & -56.27 & $0.00 *$ & -0.11 & $0.00 *$ \\
\hline & $\mathrm{X}_{1} \cdot \mathrm{X}_{1}$ & -7.60 & $0.00 *$ & 0.66 & $0.06 * *$ & -7.93 & $0.65 * * * *$ & 0.06 & $0.10 * *$ \\
\hline & $\mathrm{X}_{2} \cdot \mathrm{X}_{2}$ & 2.41 & $0.27 * * * *$ & 0.11 & $0.72 * * * *$ & -1.46 & $0.93 * * * *$ & 0.08 & $0.03 * *$ \\
\hline & $X_{1} \cdot X_{2}$ & -12.79 & $0.00 *$ & -0.01 & $0.99 * * * *$ & 40.41 & $0.11 * * *$ & 0.16 & $0.01 *$ \\
\hline
\end{tabular}

$* \mathrm{P}<0.05 ; * * \mathrm{P}<0.10 ; * * * \mathrm{P}<0.15 ; * * * * \mathrm{P}>0.20$, denoting different significant effect

\subsection{Response optimisation}

Figures 5a and 6a show the optimisation of China and India peanuts roasting, respectively. In general, all responses for both type of peanuts decreased as the roasting time and temperature increased. The composite desirability (D) of these observed optimum factors for China and India peanuts was 0.98 and 0.79 , respectively. The lower value of composite desirability of India peanuts was influenced by the individual desirability value of hardness and fracturability ( 0.55 and 0.71 , respectively). It is not suggested to prolong the temperature and time to further minimize hardness and fracturability as this will reduce the individual desirability of colour and moisture, which will reduce the composite desirability. The result 
A

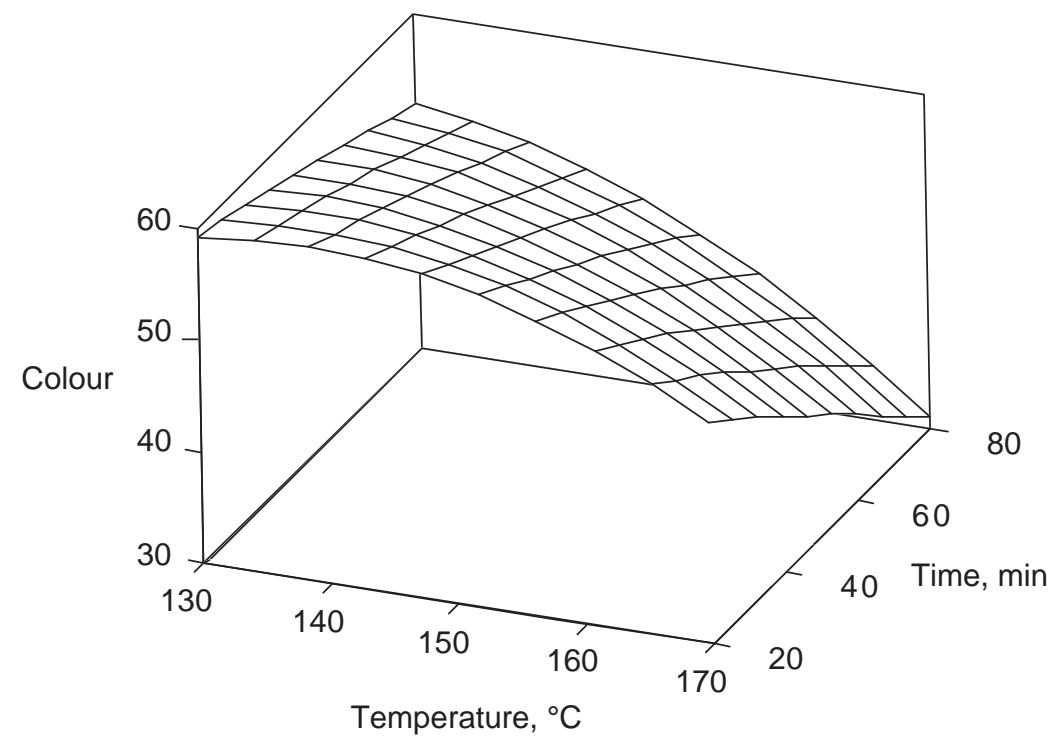

B

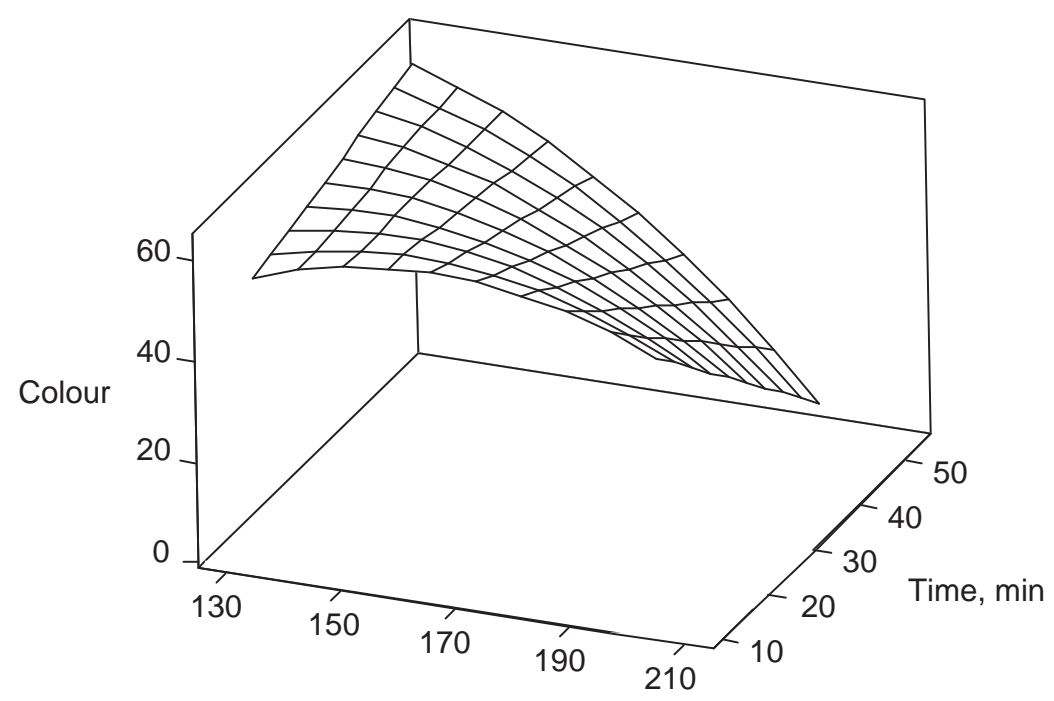

Temperature, ${ }^{\circ} \mathrm{C}$

Fig. 1. Effects of temperature $\left({ }^{\circ} \mathrm{C}\right)$ and time $(\mathrm{min})$ of roasting on colour $\left(\mathrm{L}^{*}\right)$ for $(\mathrm{A})$ China peanuts and (B) India peanuts

shows that selection of multiple responses had strong influence in the optimisation of this peanuts roasting process. In the case of India peanuts, the optimum point could not satisfy the requirements for all the responses. The differences between the D value of China and India peanuts exist because of the large differences between their textural properties, while the other properties are almost similar (Table 1). Therefore, the minimum value defined for the 
A

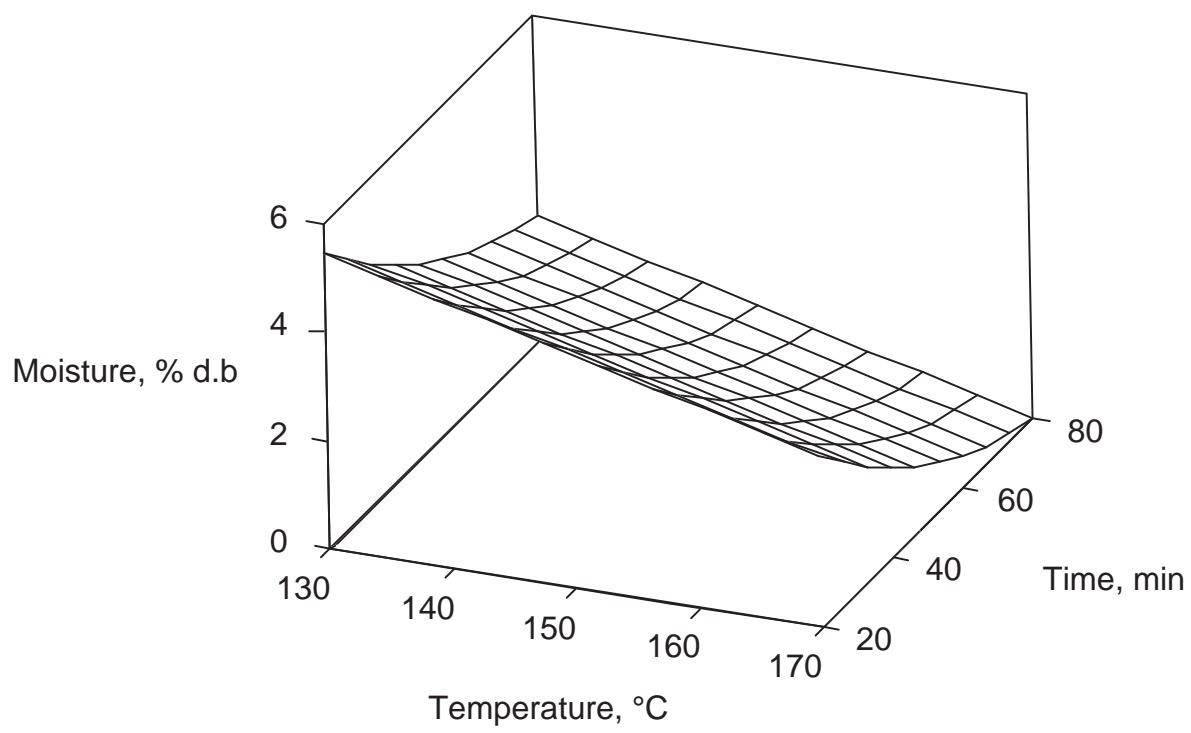

B

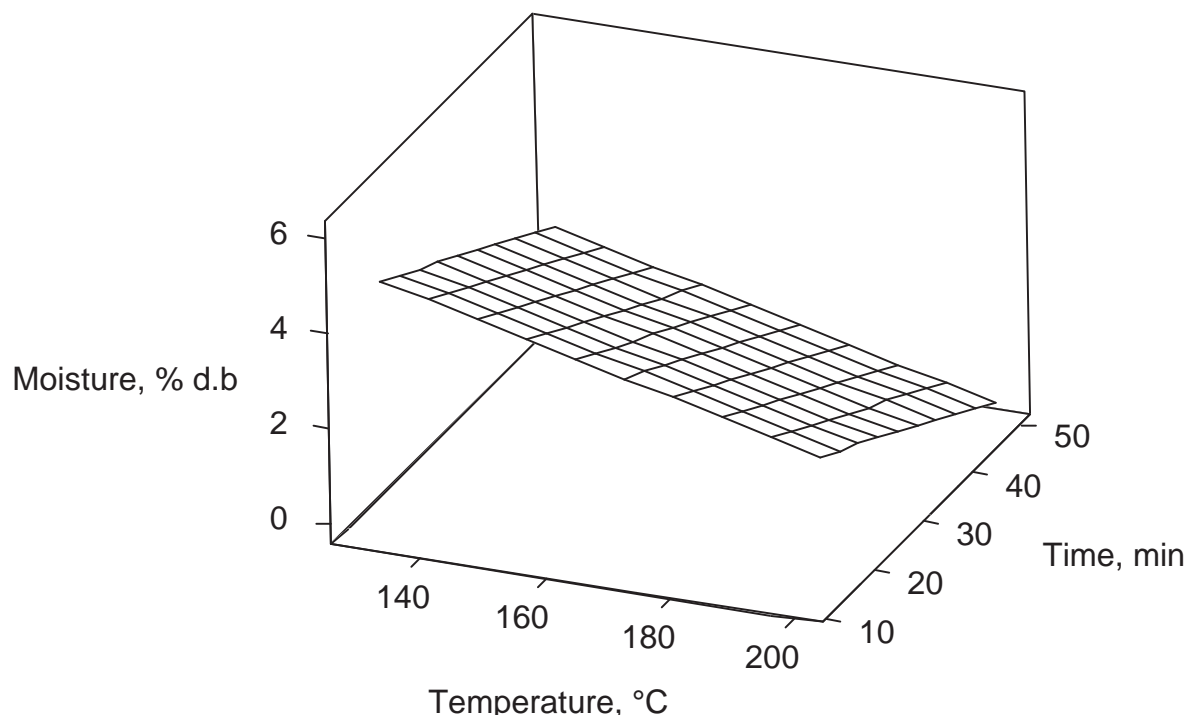

Fig. 2. Effects of temperature $\left({ }^{\circ} \mathrm{C}\right)$ and time $(\mathrm{min})$ of roasting on moisture content $(\%$ d.b.) for (A) China peanuts and (B) India peanuts

textural properties of India peanuts are still too far to reach when the other responses reached their target values.

In order to make these parameters feasible in experimental runs, these observed optimum parameters were drawn to the nearest round figures of roasting time and temperature which is $152{ }^{\circ} \mathrm{C}$ and $60 \mathrm{~min}$ for China peanuts and $158^{\circ} \mathrm{C}$ and $45 \mathrm{~min}$ for India peanuts. From these 
A

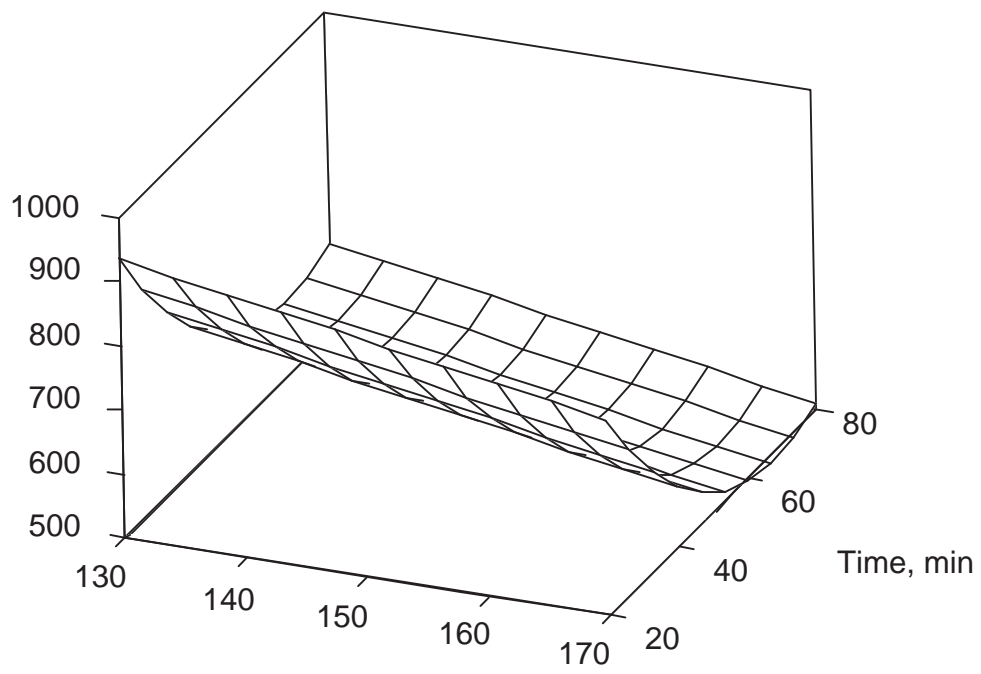

Temperature, ${ }^{\circ} \mathrm{C}$

B

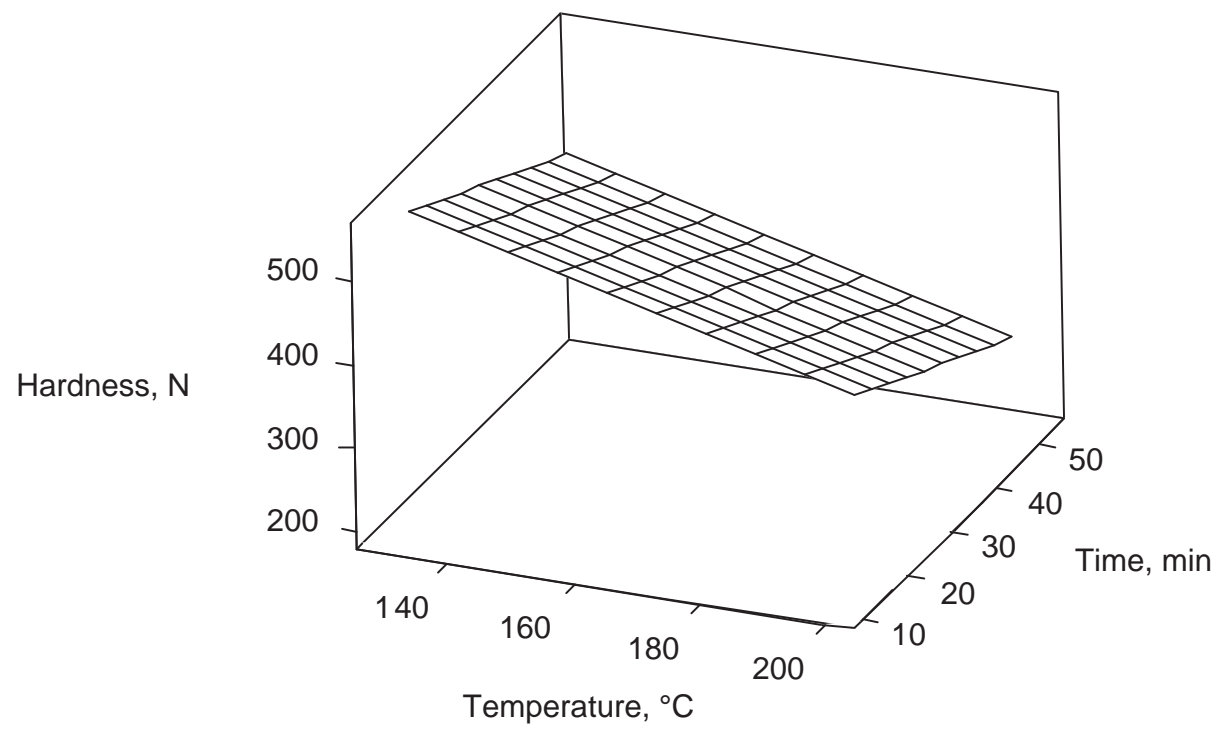

Fig. 3. Effects of temperature $\left({ }^{\circ} \mathrm{C}\right)$ and time (min)

of roasting on peanut hardness $(\mathrm{N})$ for $(\mathrm{A})$ China peanuts and $(\mathrm{B})$ India peanuts

rounded figures of factor, the individual desirability decreased slightly for all responses, which also resulted in slight reduction in composite desirability to 0.98 and 0.78 for China and India peanuts, respectively (Figs 5B and 6B).

The optimum operating conditions could be determined using the desirability function for further processing and product optimisation. Optimisation analysis was also found 
A

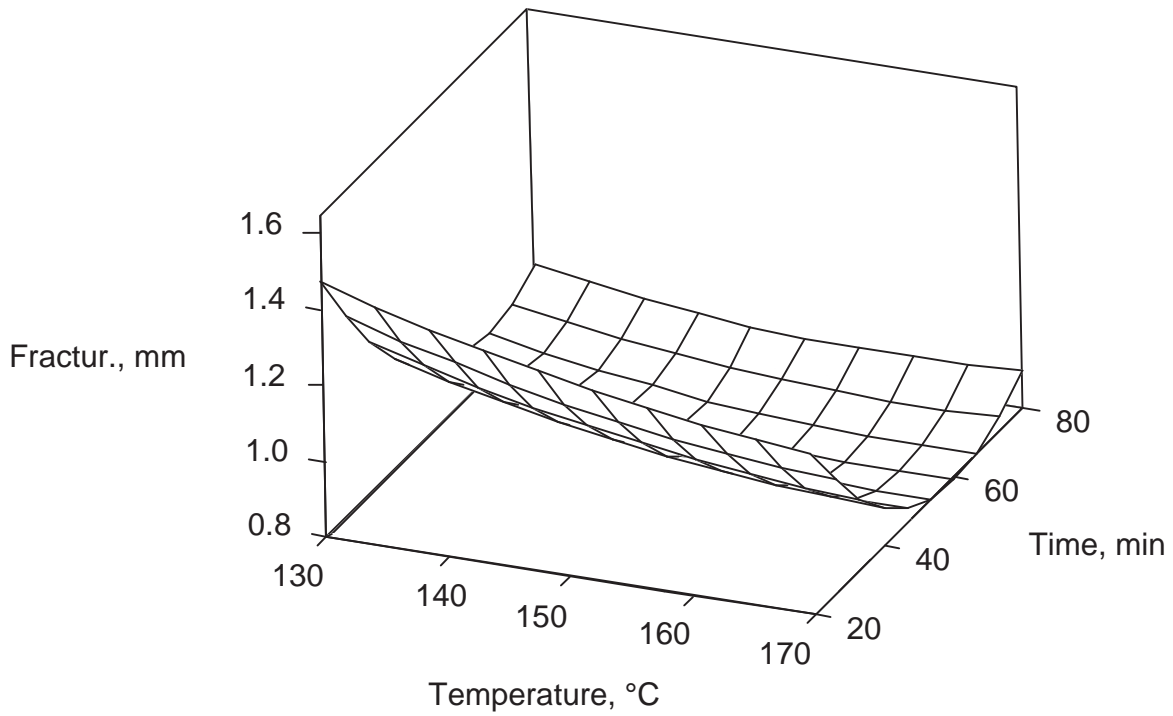

B

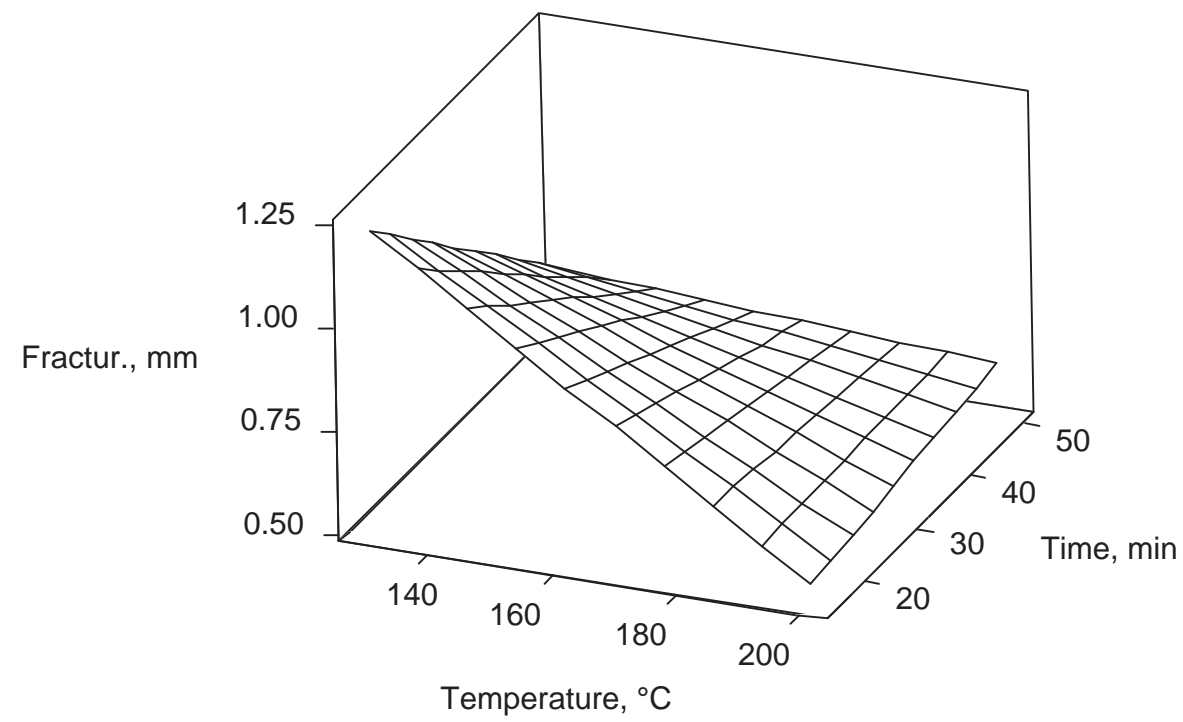

Fig. 4. Effects of temperature $\left({ }^{\circ} \mathrm{C}\right)$ and time $(\mathrm{min})$ of roasting on the fracturability $(\mathrm{mm})$ of peanut for (A) China peanuts and (B) India peanuts

successful in determining the optimum roasting conditions for sesame seed and pistachio. The optimum roasting conditions for hot air roasting of sesame seeds was found to be 155-170 ${ }^{\circ} \mathrm{C}$ and 40-60 min for the desired product type (e.g. light roasted, dark roasted) (KAHYAOGLu \& KayA, 2006) and $130-140{ }^{\circ} \mathrm{C}$ and 30-40 min for pistachio (SHAKERARDEKANI et al., 2011). 
A

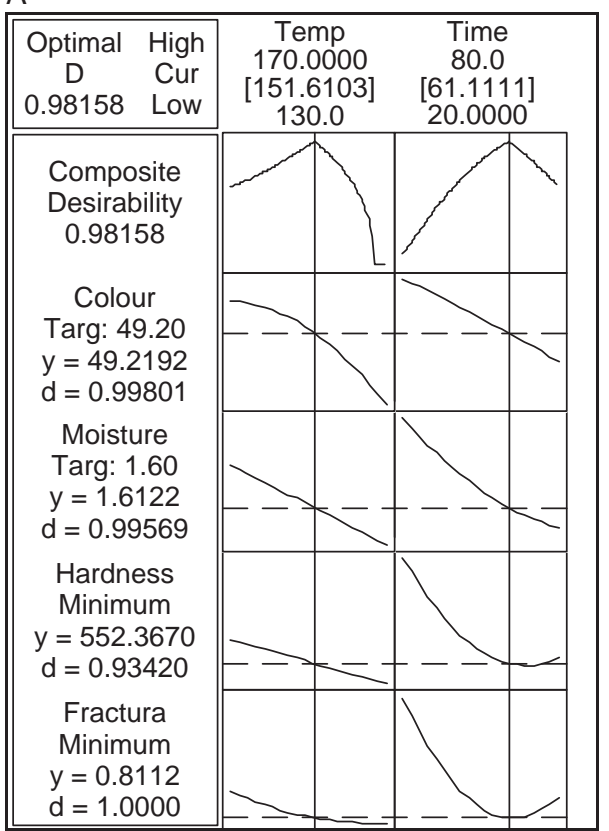

$\mathrm{B}$

\begin{tabular}{|c|c|c|}
\hline $\begin{array}{cc}\text { New } & \text { High } \\
\text { D } & \text { Cur } \\
0.97679 & \text { Low }\end{array}$ & $\begin{array}{c}\text { Temp } \\
170.0000 \\
{[152.0]} \\
130.0\end{array}$ & $\begin{array}{c}\text { Time } \\
80.0 \\
{[60.0]} \\
20.0000 \\
\end{array}$ \\
\hline $\begin{array}{c}\text { Composite } \\
\text { Desirability } \\
0.97679\end{array}$ & & \\
\hline $\begin{array}{c}\text { Colour } \\
\text { Targ: } 49.20 \\
y=49.3033 \\
d=0.98926\end{array}$ & & \\
\hline $\begin{array}{c}\text { Moisture } \\
\text { Targ: } 1.60 \\
y=1.6352 \\
d=0.98756\end{array}$ & & \\
\hline $\begin{array}{c}\text { Hardness } \\
\text { Minimum } \\
y=553.2724 \\
d=0.93181\end{array}$ & & \\
\hline $\begin{array}{c}\text { Fractura } \\
\text { Minimum } \\
y=0.8112 \\
d=1.0000\end{array}$ & & \\
\hline
\end{tabular}

Fig. 5. Response behaviour of colour, moisture content, hardness, and fracturability predicted from (A) the observed optimum condition and (B) feasible experimental condition for China peanuts

A

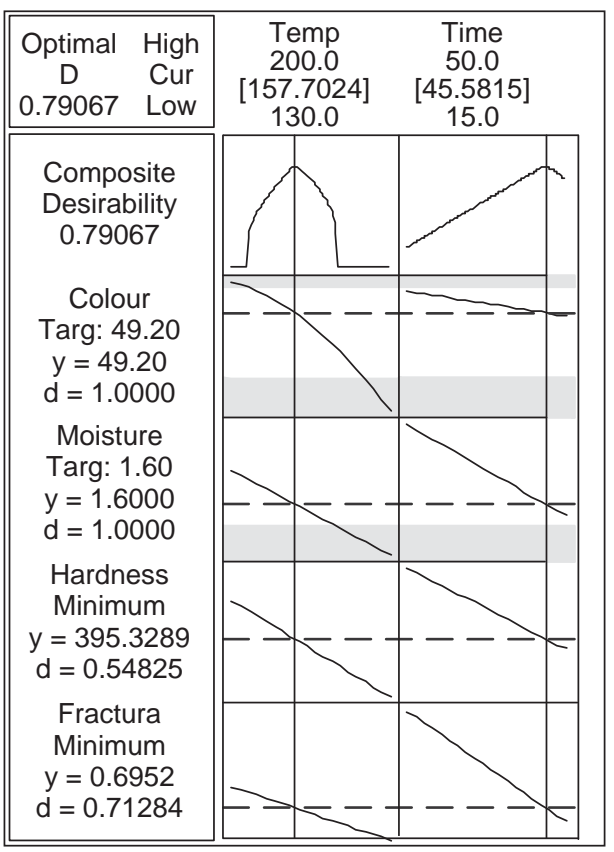

$\mathrm{B}$

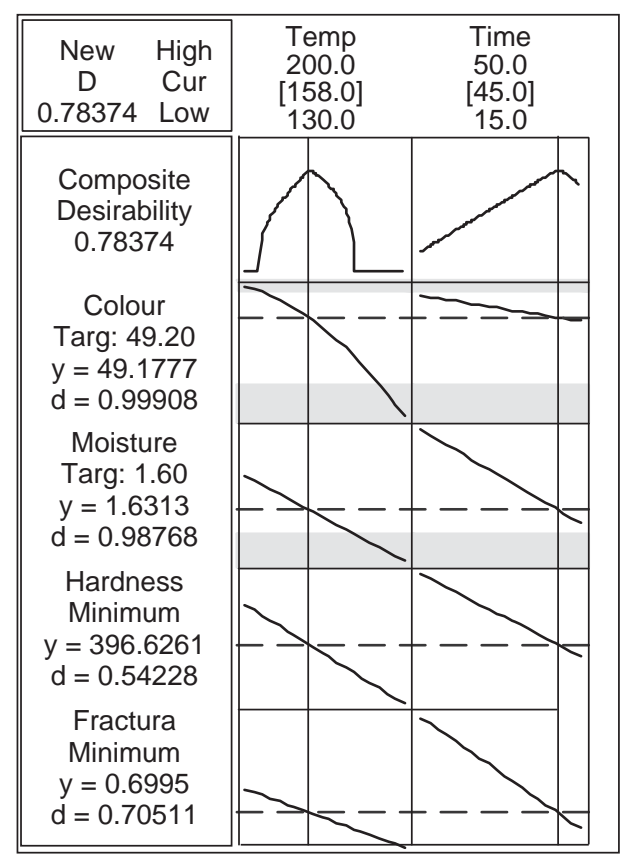

Fig. 6. Response behaviour of colour, moisture content, hardness, and fracturability predicted from (A) the observed optimum condition and (B) feasible experimental condition for India peanuts 


\subsection{Pearson's correlations among various responses of roasted peanuts}

Table 3 shows the Pearson correlation of all the responses from peanut roasting process with each other. Strong positive correlations at $\mathrm{P}<0.01$ were observed between physical properties and the textural properties, such as those between moisture content and hardness were at $r$ of 0.89 and 0.87 for China and India peanuts, respectively, moisture content and fracturability were at $r$ of 0.85 and 0.88 , and between the textural properties, $r$ were 0.98 and 0.90 . This suggests that moisture content could be used to predict the textural properties of roasted peanuts in this experiment. Moisture content proved to be an important parameter during roasting of nuts, contradicting to previous studies on roasting of pistachio kernels (Shakerardekani et al., 2011) and sesame seeds (KahYAOglu\& KaYA, 2006), but agreeing with the studies of Hung (2000) and Hung and ChinNan (1989) on roasted peanut, where textural quality either in the form of hardness, crispiness, or crunchiness is strongly related to the moisture content. As colour attribute usually associates with flavour and aroma compounds (Johnsen et al., 1988; SMYth et al., 1998) or the breakdown of the chemical structure of peanut, such as arachin (SLADE \& LEVINE, 2006), the good correlation between moisture and colour makes them a beneficial attribute in describing other changes in chemical or physical properties of peanuts during roasting.

All the responses' correlations have positive coefficient value indicating that both variables have a same direction during roasting.

Table 3. Pearson's correlation coefficients between various properties of roasted peanuts

\begin{tabular}{lllll}
\hline Type & & Colour & Moisture & Hardness \\
\hline China & Moisture & $0.883^{\mathrm{a}}$ & & \\
& Hardness & $0.657^{\mathrm{a}}$ & $0.890^{\mathrm{a}}$ & \\
& Fracturability & $0.609^{\mathrm{b}}$ & $0.848^{\mathrm{a}}$ & $0.982^{\mathrm{a}}$ \\
\multirow{2}{*}{ India } & Moisture & $0.722^{\mathrm{a}}$ & & \\
& Hardness & $0.763^{\mathrm{a}}$ & $0.865^{\mathrm{a}}$ & \\
& Fracturability & $0.669^{\mathrm{b}}$ & $0.875^{\mathrm{a}}$ & $0.901^{\mathrm{a}}$ \\
\hline
\end{tabular}

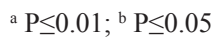

\section{Conclusions}

Roasted peanuts quality responses modelled as a function of roasting temperature and time were capable of predicting the response yield with at least $87 \%$ of accuracy. Roasting temperature was found to be the main factor governing the colour development, while time was the main factor promoting texture and moisture degradation of peanuts. With the central composite design of experiment, the optimal condition of peanut roasting was optimized by fixing target values of responses with the best definition of each roasting process response. The optimal setting, which is feasible for experimental conditions, was $152{ }^{\circ} \mathrm{C}$ and $60 \mathrm{~min}$ for China peanuts and $158^{\circ} \mathrm{C}$ and 45 minutes for India peanuts. The Pearson's correlation coefficient indicates that the textural properties of roasted peanuts in this study are well correlated with the moisture content. 


\section{References}

Akinoso, R.\& RAJI, A.O. (2011): Optimisation of oil extraction from locust bean using response surface methodology. Eur. J. Lipid Sci. Technol., 113, 245-252.

A.O.A.C. (1996): A.O.A.C. Official method of analysis, (16 ${ }^{\text {th }}$ ed). Association of Official Analytical Chemists, Washington, Method 925.40.

DemiR, A.D. \& Cronin, K. (2005): Modelling the kinetics of textural changes in hazelnuts during roasting. Simulation Modelling Pract. Theory, 13, 97-107.

De Conto, L.C., Oliveira, R.S.P., Martin, L.G.P., Chang, Y.K.\& Steel, C.J. (2012): Effects of the addition of microencapsulated omega-3 and rosemary extract on the technological and sensory quality of white pan bread. LWT-Fd Sci. Technol., 45, 103-109.

FDA (2003): Qualified health claim: letter of enforcement discretion-nuts and coronary heart disease. (Docket No. 02P-0505)

Gills, L.A.\& Resurrecion, V.A. (2000): Sensory and physical properties of peanut butter treated with palm oil and hydrogenated vegetable oil to prevent oil separation. J. Fd Sci., 65, 173-180.

Hung, Y.C. (2000): Predicting the effect of drying conditions on the textural properties of roasted peanuts. Trans. ASAE, 32, 968-972.

Hung, Y.C.\& Chinnan, M.S. (1989): Mechanical texture measurement of whole and chopped peanuts. Peanut Sci., 16, 32-37.

Johnsen, P.B., Civille, G.V., Vercellotti, J.R., Sanders, T.H.\& Dus, C.A. (1988): Development of a lexicon for the description of peanut flavour. J. Sensory Stud., 3, 9-17.

KahyaOGLU, T. (2008): Optimisation of the pistachio nut roasting process using response surface methodology and gene expression programming. $L W T, 41,26-33$.

KahyaOglu, T.\& Kaya, S. (2006): Determination of optimum processing conditions for hot-air roasting of hulled sesame seeds using response surface methodology. J. Sci. Fd Agric., 86, 1452-1459.

McKiernan, F., Lokko, P., Kuevi, A., Sales, R.L., Costa, N.M.B., Bressan, J., Alfenas, R.C.G. \& Mattes, R.D. (2010): Effects of peanut processing on body weight and fasting plasma lipids. Br. J. Nutr., 104, 418-426.

Megahed, M.G. (2001): Microwave roasting of peanuts: Effects on oil characteristics and composition. Nahrung-Fd, $45,255-257$.

Mendes, L.C., De Menezes, H.C., Aparecida, M.\& Da Silva, A.P. (2001): Optimisation of the roasting of robusta coffee (C. Canephora conillon) using acceptability tests and RSM. Fd Qual. Preference, 12, 153-162.

Nikzadeh, V.\& Sedaghat, N. (2008): Physical and sensory changes in pistachio nuts as affected by roasting temperature and storage. Am.-Eurasian J. Agric. Environ. Sci., 4, 478-483.

Özcan, M. \& SEVEn, S. (2003): Physical and chemical analysis and fatty acid composition of peanut, peanut oil and peanut butter from ÇOM and NC-7 cultivars. Grasas Aceites, 54, 12-18.

Özdemir, M. \& Devres, O. (2000): Kinetics of colour changes of hazelnuts during roasting. J. Fd Engng, 44, 31-38.

Rodrigues, A.C., Ströher, G.L., Freitas, J.V., Visentainer, C.C., \& Oliveira, N.E.D.S. (2011): The effect of genotype and roasting on the fatty acid composition of peanuts. Fd Res. Int., 44, 187-192.

SAKLAR, S., Ungan, S.\& Katnas, S. (1999): Instrumental crispness and crunchiness of roasted hazelnuts and correlations with sensory assessment. J. Fd Sci., 64, 1015-1019.

SAKLAR, S., Ungan, S. \& Katnas, S. (2003): Microstructural changes in hazelnut during roasting. Fd Res. Int., 36, 19-23.

Shakerardekani, A., Karim, R., Mohd Ghazali, H. \& Chin, N.L. (2011): Effect of roasting conditions on hardness, moisture content and colour of pistachio kernels. Int. Fd Res. J., 18, 704-710.

Slade, L.\& Levine, H. (2006): Optimisation of roasting process and product quality of peanuts. J. Thermal Anal. Colourimetry, 83, 163-166.

Smyth, D.A., Macku, C., Holloway, O.E., Deming, D.M., Slade, L. \& Levine, H. (1998): Evaluation of analytical methods for optimizing peanut roasting for snack foods. Peanut Sci., 25, 70-76.

TAn, M.C., Chin, N.L.\& Yusof, Y.A. (2012): A Box-Behnken design for determining the optimum experimental condition of cake batter mixing. Fd Bioprocess Technol.: Intern. J., 5, 972-982

Tomlins, K., Rukuni, T., Mutungamiri, A., Mandeya, S. \& Swetman, A. (2007): Effect of roasting time and storage time on sensory attributes and consumer acceptability of peanut butters in southern Africa. Trop. Sci., 47, $165-182$.

USDA (2011): Oilseeds: World markets and trade monthly circular. United States Department of Agriculture: Foreign Agricultural Service. http://www.fas.usda.gov/oilseeds/Current/default.asp. Access: 2011/7/14. 
WitLich, R.K. (1952): Peanut butter. II. Effect of roasting and blanching on the thiamin content of peanut butter. Fd Technol., 6, 199-200.

Woodroof, J.G. (1983): Peanut butter. -in Peanuts production, processing, products, (3 ${ }^{\text {rd }}$ ed.), The AVI Publishing Company, Connecticut, pp. 181-225.

Youn, K.S. \& Chung, H.S. (2011): Optimisation of the roasting temperature and time for preparation of coffee-like maize beverage using the response surface methodology. Fd Sci. Technol., 46, 305-310. 